research on new radioactive substances, while on behalf of the Commission for Morphological Medical Sciences, Prof. M. G. Leplat refers to a study of senescence. The Scientific Commission for Pathology of Transmissible Diseases, Colonial Pathology and Hygiene has studied the extension of bilharziasis and its control, rickettsiosis and filariasis, while the Commission for Clinical Sciences has been investigating the problems of antibiotics and the mode of action of sulphonamides. The Commission for Applied Chemistry has investigated the constitution and chemical properties of mineral oils, and a new Scientific Commission has been set up for the study of problems of nuclear energy.

\section{National Institute of Sciences of India : Elections}

Ar the annual general meeting of the National Institute of Sciences of India, held at Patna on January 1, the following new fellows were elected: Dr. B. S. Bhimachar, fisheries officer with the Government of Mysore, Bangalore; Pratap Chandra Bose, chief engineer, Corporation of Calcutta ; Dr. Satya Charan Chatterjee, head of the Department of Geography, Patna College, Bankipur, Patna; Jehangir Fardunji Dastur, head of the Division of Mycology, Indian Agricultural Research Institute, New Delhi; Dr. Arun Kumar Dutta, reader in physics, Dacea University; Dr. Rukmini Kishore Dutta Roy, Geological Survey of India, Calcutta; Dr. Robert E. Heilig, chief physician, Jaipur; Dr. Kolar Ramakrishna Krishnawami, director of industries, Bihar, Patna; R. A. MacGregor, formerly chief metallurgist to the Government of India, Calcutta; Ganesh Chandra Mitter, chief assayer, His Majesty's Mint, Bombay, and honorary professor of industrial chemistry, Royal Institute of Science, Bombay ; Dr. Mahadeo Atmaram Moghe, professor of zoology, College of Science, Nagpur, and head of the Department of Zoology and dean of the Faculty of Science, Nagpur University; Dr. S. P. Raju, director of the Engineering Research Department, H.E.H. Nizam's Government, Hyderabad, Deccan; Dr. Srinivasa Ramanujam, Central Potato Research Institute, New Delhi; Dr. Subbarao Ramachandra Rao, professor of physics, Central College, Bangalore; Dr. Jyotis Chandra Ray, director, Indian Institute for Medical Research, Calcutta.

\section{Physiology and Pathology of Animal Reproduction}

THE First International Congress on the Physiology and Pathology of Animal Reproduction and on Artificial Insemination will be held during June 23-30 at Milan. On June 21 a preliminary conference will take place, under the auspices of the United Nations Educational, Scientific and Cultural Organisation, at which a limited number of Italian and foreign specialists will discuss "Interacting Substances of Ova and Sperm, and Parthenogenesis". The Scientific Commission of the Congress will arrange the papers sent to the Congress in sections according to subject; full sessions will discuss certain themes of general interest. The subjects the Congress is to deal with are : (a) biological problems of animal reproduction ; (b) breeding problems of animal reproduction; (c) pathological problems of animal reproduction; (d) methodological and practical problems of artificial insemination of animals ; $(e)$ legislative and organisational problems of artificial insemination and of animal reproduction. An exhibition of related material and books, and also visits to breeding stations and scientific institutions, are being arranged. Papers for the Congress must be received by March 31. Detailed information can be obtained from Prof. T. Bonadonna, secretary-general of the Congress (via Bronzetti 17, Milan). The subscriptions are: for mombers actually taking part in the Congress, 8 dollars or $£ 2$; for others, 4 dollars or $£ 1$.

\section{International Symposium on Noise}

An international symposium on noise is to be held by the Acoustics Group of the Physical Society in association with the Royal Institute of British Architects during July 14-16, in the hall of the Institute at Portland Place, London, W.1. The draft programme provides for four sections: (1) noise measurement; (2) field and laboratory studies; (3) reduction of noise, air-borne and structure-borne; (4) building practice, as applied in houses and flats, factories, theatres, concert halls, etc. Contributions to the symposium are invited, and those who intend to read papers or submit written contributions are asked to inform the recorder, Dr. A. J. King, not later than March 31. Anyone wishing to have accommodation reserved should apply as soon as possible to the Accommodation Officer. The address for him and the Recorder of the Symposium is : Acoustics Group, Physical Society, I Lowther Gardens, Prince Consort Road, London, S.W.7.

\section{Royal Meteorological Society}

THE following have been elected officers of the Royal Meteorological Society President, Dr. G. M. B. Dobson; Vice-Presidents, Capt. L. G. Garbett, E. Gold, G. Manley, J. F. Shipley, A. Thomson (for Canada) and J. Paton (for Scotland); Treasurer, W. N. Witehell ; Secretaries, E. L. Hawke and Wing-Comdr. R. M. Poulter; Scottish Secretary, A. J. Drummond; Foreign Secretary, L. C. W. Bonacina ; Councillors, A. C. Best, A. W. Brewer, J. S. Forrest, Major H. C. Gunton, W. G. Kendrew, I. T. D. Kirkpatrick, Dr. A. R. Meetham, Dr. F. J. Scrase, Prof. P. A. Sheppard, A. E. Slater, Lieut.Comdr. P. C. Spink and Dr. T. W. Wormell.

\section{Ethics and Science Conference}

THE Ethics and Science Conference arranged by the British Social Hygiene Council will be held on Friday, March 19, at the Livingstone Hall, London, S.W.1. The main theme of the Conference will be "Society and the Individual", each of the two sessions being devoted to a different aspect of this problem; the speakers at the morning session considering "The Value Society Sets upon the Individual", and at the afternoon session "The Values the Individual Sets before Himself". The chair will be taken by Mr. L. J. F. Brimble and Dr. E. B. Strauss, and the speakers will include Mr. F. Ian G. Rawlins, Canon Marcus Knight, Mr. Kenneth Walker, Dr. E. H. Larkin, Mr. John Mackay-Mure, Mrs. Joan B. Thompson, Father Leycester King, Dr. Mary Smith, and others. Time will be allowed for discussion at both the morning and afternoon sessions and at an open meeting in the evening. It is hoped that, as a result, fresh light will be thrown upon the problems arising from the apparent conflict between the scientific and spiritual interpretations of life. Further information and tickets (members of the Council, 2s. 6d.; others, 3s. 6d.) may be obtained from the British Social Hygiene Council, Dept. S.J.1, Tavistock House North, Tavistock Square, London, W.C.1. 